\title{
Soil Quality Changes and Quality Status: A Case Study of the Subtropical China Region Ultisol
}

\author{
A. C. Odunze ${ }^{1,2^{\star}}$, Wu Jinshui ${ }^{1 \star \star}$, Liu Shoulong ${ }^{1}$, Zhu Hanhua $^{1}$, Ge Tida $^{1}$, \\ Wang $\mathrm{Yi}^{1}$ and Luo Qiao
}

${ }^{1}$ Key Laboratory of Agro-ecological Processes in Subtropical Region, Institute of Subtropical Agriculture, Chinese Academy of Sciences, Changsha 410125, China.

${ }^{2}$ Present affiliation: Department of Soil Science/IAR, Faculty of Agriculture, Ahmadu Bello University, P. M. B 1044, Zaria Nigeria.

\author{
Case Study
}

Received $23^{\text {rd }}$ January 2012

Accepted $24^{\text {th }}$ February 2012

Online Ready $7^{\text {th }}$ March 2012

\section{ABSTRACT}

Aims: To provide a soil quality assessment frame work and threshold limits for assessing soil quality in Ultisol of subtropical China region.

Study Design: Selected minimum data set for soil quality assessment and threshold limits for the study were total carbon, nitrogen, soil $\mathrm{pH}$ and phosphorus, biomass carbon, nitrogen and phosphorus, maize grain and fresh potato tuber yields. Soil data (2000-2010), maize grain and fresh potato yield data (2000-2009) from a long term experiment under the Institute of subtropical Agriculture, China were analyzed using the SAS statistical package and means were graphically compared to determine threshold limits for selected data set and fitted into a soil quality model.

Place and Duration of Study: The key Laboratory for Agro-ecological Processes in Subtropical Regions, Chinese Academy of Sciences; Institute of Subtropical Agriculture, Changsha, Hunan China long-term experimental site in Taoyuan county, conducted from the year 2000 to 2010.

Methodology: Soils samples at the experimental fields were obtained from depths $0-20$ $\mathrm{cm}$ using an auger at each replicate in triplicates and homogenized to obtain a composite sub sample, air-dried, sieved through $2.0 \mathrm{~mm}$ to obtain samples for analysis in the Laboratory. Parameters analyzed for were organic carbon concentration, measured by the combustion method using an automated $\mathrm{C} / \mathrm{N}$ analyzer (Vario MAX CN, Elemental Co., Germany) while total nitrogen was by the Kjeldahl method of ISSCAS (1978). Microbial carbon, nitrogen and phosphorus levels were determined using the chloroform-fumigationextraction method (Jenkinson and Powlson, 1976; Vance et al., 1987; Brookes et al.,

\footnotetext{
*Corresponding author: Email: odunzeac@yahoo.com; odunzeac@gmail.com; **jswu@isa.ac.cn;
} 
1982) and adopting the conversion factors 0.45 (Wu et al., 1990), 0.45 (Brookes et al., 1985), and 0.29 (Wu et al., 2000) respectively for the C, N and P. Extractable $\mathrm{N}$ and Olson $P$ were taken from values obtained from the non fumigated soil samples. Data obtained were statistically analyzed using the SAS package for ANOVA and significant means were separated using the Duncan's New Multiple Range Test (DNMRT). Treatment means were also matched graphically to delineate critical threshold limits between classes for each parameter. Soil quality was assessed by using the Parr et al. (1992) equation; SQ $=f(S P, P, E, H, E R, B D, F Q, M I)$; where $S Q=$ soil quality, $S P=$ soil properties, $P=$ potential productivity, $\mathrm{E}=$ environmental factor, $\mathrm{H}=$ health (human/animal), $\mathrm{ER}=$ erodibility, $\mathrm{BD}=$ biodiversity, $\mathrm{FQ}=$ food quality and $\mathrm{Ml}=$ management input. $\mathrm{A}$ score scale of 1 to 5 was used in the assessment of parameters in the model; where 1 is best and 5 is the worst condition. However, E, H, ER, FQ and MI were each scored 1.0 because the long-term experiment has an environmental component, health factor, biodiversity, food quality and management input components that are being optimally managed. Therefore $S Q=f(S P, P)$ was used to assess quality of the Ultisol at the uplands and slope land locations.

Results: At the uplands, the practice of maize-rape/marsh residue+NK $\left(8.54 \mathrm{gkg}^{-1} \mathrm{C}, 1.0\right.$ $\mathrm{gkg}^{-1} \mathrm{~N}$ and $\left.5.67 \mathrm{mgkg}^{-1} \mathrm{P}\right)$ treatments could be rotated with Maize-rape/nil fertilizer $(7.51$ $\mathrm{gkg}^{-1} \mathrm{C}, 0.87 \mathrm{gkg}^{-1}$ and $0.39 \mathrm{mgkg}^{-1} \mathrm{P}$ ) to encourage improved soil quality by allowing for more years with soil carbon sequestration, nitrogen and phosphorus credit than years of depletion and discourage soil degradation. At the slope lands, treatments that combined application of organic and inorganic fertilizer materials [Sweet potato-rape/NP+straw (7.18 $\mathrm{gkg}^{-1} \mathrm{C}, 0.88 \mathrm{gkg}^{-1} \mathrm{~N}$ and $\left.0.38 \mathrm{mgkg}^{-1} \mathrm{P}\right)$ and Peanut-broadbean/NP+straw $\left(6.81 \mathrm{gkg}^{-1} \mathrm{C}\right.$, $0.86 \mathrm{gkg}^{-1} \mathrm{~N}$ and $\left.0.38 \mathrm{mgkg}^{-1} \mathrm{P}\right)$ ] improved soil quality significantly over time by sequestering significantly higher total carbon, nitrogen and phosphorus better than sole inorganic fertilizer [Sweet potato-rape/NPK $\left(6.52 \mathrm{gkg}^{-1} \mathrm{C}, 0.81 \mathrm{gkg}^{-1} \mathrm{~N}\right.$ and $0.38 \mathrm{mgkg}^{-1}$ P)].

Conclusion: Ultisol at the upland positions had better quality $\left(\mathrm{SQ}_{1}\right)$ than those at the slope $\left(\mathrm{SQ}_{2}\right)$ positions. Threshold limits for nutrients, $\mathrm{pH}$ and yield of maize and Fresh Potato tubers in the subtropical China region Ultisol was developed.

Keywords: Soil quality; sustainable soil productivity; threshold limits; soil health; land use management.

\section{INTRODUCTION}

The rate of growth of global grain production dropped from 3\% in the 1970 s to $1.3 \%$ in the 1983-1993 period, and one of the key reasons of this decline is inadequate soil and water management (Steer, 1998). Protection of soil quality under intensive land use and fast economic development has therefore become a major challenge for sustainable resource use in the developing world (Doran et al., 1996; Doran and Safley, 1997; Karlen et al., 1997). In order that soil quality must be adequately protected, basic assessment of soil health and quality is necessary to evaluate the degradation status and changing trends following different land use and smallholder management interventions (Lal and Stewart, 1995, Larson and Pierce, 1994). This is intended to provide yardstick for monitoring and evaluation of the soil status over time, mitigate degradation trends and ensure environmental and crop production sustainability (Hedlund et al., 2003; Doran et al 1997; Doran and Zeiss, 2000). The continued absence of easily applicable checklist and threshold limits for monitoring soil 
quality negates scientists' efforts at ensuring sustainable crop production and environmental quality maintenance.

Enhancing soil quality is a key factor in sustaining soil resources for high quality soils to be better producers of food and fibre for the world's growing population and also play a major role in stabilizing natural ecosystems, enhancing air and water quality (Gregorich et al., 1994; Doran, 2002; Karlen et al., 1997), improving cropland per capita output and sustaining national food security.

Changes in soil quality can be assessed by measuring appropriate indicators and comparing them with desired values (critical limits or threshold level), at different time intervals, for a specific use in a selected agro-ecosystem. Such a monitoring system will provide information on the effectiveness of selected farming system, land use practices, technologies and policies (Arshad and Martin, 2002). Gomez et al., (1996) proposed a framework for evaluating sustainability at farm level in the Philippines based on field indicators that take into account both farmer's satisfaction and resource conservation. They observed that high yield, low labor requirement, low input cost, high profit, and stability are some features that are likely to enhance farmer satisfaction. The minimum data set that is hoped will benefit farmers, researchers and Extension workers in subtropical China was selected and evaluated in this study.

It would be necessary to determine quality status of soils under various land use management systems in China, as this would guide land use policy formulation (Lal and Stewarts, 1995; Barrios and Trejo, 2003). Also, critical limits for quality assessment of soils would benefit quick diagnostics and decision making of soil status by farmers, Extension experts and Research Scientists (Andrews and Carroll, 2001; Barrior and Trejo, 2003), and was attempted in this study on Ultisol.

Objective of this study include -

i) Assessing Land Use Systems for soil quality status and changing trends to advance novel land use management strategies for adoption across China subtropical regions Ultisol.

ii) Determining threshold limits for selected soil nutrients and yield of maize and potato in Ultisol of the region.

\section{MATERIALS AND METHODS}

The experiment was conducted in Taoyuan County, at a hilly site $\left(111^{\circ} 31^{\prime} \mathrm{E}, 29^{\circ} 14^{\prime} \mathrm{N}\right)$ in the middle of subtropical region of China. The site has a gradient of $8^{\circ}$, a mean elevation of 106 $\mathrm{m}$, annual temperature of $16.8^{\circ} \mathrm{C}$ and annual rainfall of $1,330 \mathrm{~mm}$. Soil at the experimental site was a clay loam classified as Ultisol (USDA Soil Taxonomy, 1998) developed from Quaternary red earth.

\subsection{Soil Quality and Changing Trends Assessment}

This study relied on soil, maize and potato yield data on the long-term experiment to assess soil quality and changing trends from 2000 to 2010. The basic soil quality indicators selected for a minimum data set in this study include: 
i) data on total carbon, total nitrogen, total phosphorus and soil pH from 2000-2010.

ii) data on microbial biomass carbon, nitrogen and phosphorus 2000-2006.

iii) data on maize grain and Sweet Potato fresh weight yields 2000-2009.

Basic soil quality indicators selected are also relevant to existing soil data bases (Doran and Parkin, 1994; Andrew and Carroll, 2001) at the Institute of Subtropical Agriculture, Changsha, China. Trials monitored were both at the uplands and slope lands were rotation experiments having the following treatments were executed:

In the uplands the following trials were compared:

i) Fallow/nil fertilizer application (Fnf)

ii) Maize-Rape/Nil fertilizer application (M-R/nf)

iii) Maize-Rape/NPK fertilizer application (M-R/NPK)

iv) Maize-Rape/NK+ residue $(\mathrm{M}-\mathrm{R} / \mathrm{NK}+\mathrm{R})$

v) Sweet Potato-Rape/Straw+NP (P-R/S+NP)

and in the slope land, the following trials were compared:

i) Fallow-Nil fertilizer (Fnf)

ii) Sweet potato-Rape/Nil fertilizer (Sp-R/nf)

iii) Sweet potato-Rape/NPK (Sp-R/NPK)

iv) Sweet potato-Rape/NP+straw $(\mathrm{Sp}-\mathrm{R} / \mathrm{NP}+\mathrm{S})$

v) Pea nut-Broad bean/NP+straw $(\mathrm{Pn}-\mathrm{Bb} / \mathrm{NP}+\mathrm{S})$

vi) Maize-Barley/NK+ maize residue $(\mathrm{M}-\mathrm{B} / \mathrm{NK}+\mathrm{R})$

Plot size for each treatment was $3 \mathrm{~m}$ by $7 \mathrm{~m}$ i.e., $21 \mathrm{~m}^{2}$ while straw rate was 12.7 tha $^{-1} \mathrm{yr}^{-1}$, marsh residue was 10.0 tha $^{-1} \mathrm{yr}^{-1}$ and fertilizer rates were $224 \mathrm{Kg} \mathrm{N} \mathrm{ha}^{-1} \mathrm{yr}^{-1}, 52 \mathrm{Kg} \mathrm{P} \mathrm{ha}^{-1} \mathrm{yr}^{-1}$ and $174 \mathrm{Kg} \mathrm{K} \mathrm{ha}^{-1} \mathrm{yr}^{-1}$. The treatments were replicated three times and maintained for the period 2000-2006/2010. However, maize yield was monitored on M-R/nf, M-R/NPK and M$\mathrm{R} / \mathrm{NK}+\mathrm{R}$ treatments from 2000-2009 at the uplands. Potato yield was assessed on $\mathrm{Sp}-\mathrm{R} / \mathrm{nf}$, $\mathrm{Sp}-\mathrm{R} / \mathrm{NPK}$ and $\mathrm{Sp}-\mathrm{R} / \mathrm{NP}+\mathrm{S}$ on the slope lands.

\subsection{Laboratory Analysis}

Soil samples at the experimental fields were obtained from depths $0-20 \mathrm{~cm}$ using an auger at each replicate in triplicates and homogenized to obtain a composite sub sample. The soils were air-dried, sieved through $2.0 \mathrm{~mm}$ to obtain samples for analysis in the Laboratory. Parameters analyzed for were organic carbon concentration, measured by the combustion method using an automated $\mathrm{C} / \mathrm{N}$ analyzer (Vario MAX CN, Elemental Co., Germany) while total nitrogen was by the Kjeldahl method of ISSCAS (1978). Microbial carbon, nitrogen and phosphorus levels were determined using the chloroform-fumigation-extraction method (Jenkinson and Powlson, 1976; Vance et al., 1987; Brookes et al., 1982) and adopting the conversion factors 0.45 (Wu et al., 1990), 0.45 (Brookes et al., 1985), and 0.29 (Wu et al. 2000) respectively for the $C, N$ and $P$. Extractable $N$ and Olson $P$ was taken from values obtained from the non fumigated soil samples. Data obtained were statistically analyzed using the SAS package for ANOVA and significant means were separated using the Duncan's new multiple range test (DNMRT). Treatment means were also matched graphically to delineate critical threshold limits between classes for each parameter. Soil quality was assessed by using the Parr et al. (1992) equation; $S Q=f(S P, P, E, H, E R, B D, F Q$, $\mathrm{MI}$ ); where $\mathrm{SQ}=$ soil quality, $\mathrm{SP}=$ soil properties, $\mathrm{P}=$ potential productivity, $\mathrm{E}=$ =environmental 
factor, $\mathrm{H}=$ health (human/animal), $\mathrm{ER}=$ erodibility, $\mathrm{BD}=$ biodiversity, $\mathrm{FQ}=$ food quality and $\mathrm{MI}=$ management input. A score scale of 1 to 5 was used in the assessment of parameters in the model; where 1 is best and 5 is the worst condition. However, E, H, ER, FQ and MI were each scored 1.0 because the long-term experiment has an environmental component, health factor, biodiversity, food quality and management input components that are being optimally managed. Therefore $S Q=f(S P, P)$ was used to assess quality of the Ultisol at the uplands and slope land locations.

\section{RESULTS AND DISCUSSION}

\subsection{Uplands Assessment}

Table 1 shows that in the uplands, M-R/R+NK $\left(8.54 \mathrm{gkg}^{-1}\right)$ and Sp-R /S+NP $\left(8.43 \mathrm{gkg}^{-1}\right)$ treatments significantly $(P<0.05)$ sequestered higher total carbon to soils better than $M$ R/NPK $\left(8.06 \mathrm{gkg}^{-1}\right), \mathrm{M}-\mathrm{R} / \mathrm{nf}\left(7.51 \mathrm{gkg}^{-1}\right)$ and F/nf $\left(7.62 \mathrm{gkg}^{-1}\right)$ treatments. This suggests that total carbon increase in these Ultisol were strongly influenced by organic matter additions in the forms of either marsh residue or straw. Therefore, treatments with $M-R / R+N K$ and $S p-$ $\mathrm{R} / \mathrm{S}+\mathrm{NP}$ in the Uplands sequestered higher carbon in soils thereby converting and storing more atmospheric carbon dioxide as soil carbon (carbon sequestration) and impacting on global warming better than the other treatments evaluated.

Total nitrogen content of the soils were also significantly $(\mathrm{P}<0.05)$ enhanced under Sp$\mathrm{R} / \mathrm{S}+\mathrm{NP}\left(1.00 \mathrm{~g} \mathrm{~kg}^{-1}\right)$, and $\mathrm{M}-\mathrm{R} / \mathrm{R}+\mathrm{NK}\left(1.00 \mathrm{~g} \mathrm{~kg}^{-1}\right)$ treatments than the others (Table 1). This suggests that addition of inorganic NP and NK fertilizers to organic matter (straw or marsh residue) enhanced total nitrogen contribution (Wu, 2011; Tida et al., 2011). Also, total phosphorus was significantly $(P<0.05)$ contributed by $M-R / R+N K\left(0.51 \mathrm{mg} \mathrm{kg}^{-1}\right)$, followed by $\mathrm{Sp}-\mathrm{R} / \mathrm{S}+\mathrm{NP}\left(0.47 \mathrm{mg} \mathrm{kg}^{-1}\right)$ treatment and M-R/NPK $\left(0.47 \mathrm{mg} \mathrm{kg}^{-1}\right)$ treatment. These results were significantly higher than total $P$ values from treatments without fertilizer application (organic or inorganic). This means that fertilizer materials would be necessary to support and improve soil phosphorus status when the upland soils are used for intensive crop production. The results therefore show that combined application of organic matter (M-R/R+NK and Sp$\mathrm{R} / \mathrm{S}+\mathrm{NP}$ ), sequestered significantly higher total carbon (8.54 and $8.43 \mathrm{~g} \mathrm{~kg}^{-1}$ resp.), total nitrogen (1.00 and $1.00 \mathrm{~g} \mathrm{~kg}^{-1}$ resp.) and total phosphorus (0.47 and $0.51 \mathrm{mg} \mathrm{kg}^{-1}$ resp.) than treatments without organic inputs. Treatments with organic matter inputs significantly moderated soil acidity ( $\mathrm{pH} 5.78$ and 5.67 respectively). However M-R/NPK (pH 5.68) resulted in soil acidity rating that was not significantly $(\mathrm{P}<0.05)$ different with $\mathrm{M}-\mathrm{R} / \mathrm{R}+\mathrm{NK}(\mathrm{pH}$ 5.67) and $M-R / n f(p H ~ 5.66)$. The $F / n f, M-R / n f$, and $M-R / N P K$ treatments resulted in significantly lower total carbon, total nitrogen and total phosphorus (Table 1) implying a higher risk of soil degradation with respect to the other two treatments under a long-term use. This supports the views of Reginald et al., (2006) who observed in a similar study that control (Nil Fertilizer Treatments) and $\mathrm{N}$ alone resulted in degradation compared to a reference soil (no fertilizer/manure, no crop), and treatments with NP alone or sub-optimal rates of NPK were on the verge of degradation. 
Table 1. Upland total carbon, nitrogen, phosphorus and pH of soils during $\mathbf{2 0 0 0 - 2 0 1 0}$

\begin{tabular}{lllll}
\hline Treatments & \multicolumn{1}{l}{ Total Carbon } & Total Nitrogen & Total Phosphorus & pH \\
\cline { 2 - 4 } & $\mathbf{g ~ k g}$ & & $\mathbf{m g ~ k g}$ & \\
\hline F/nf & $7.62 \mathrm{c}$ & $0.92 \mathrm{c}$ & $0.41 \mathrm{c}$ & $5.55 \mathrm{~b}$ \\
$\mathrm{M}-\mathrm{R} / \mathrm{nf}$ & $7.51 \mathrm{c}$ & $0.87 \mathrm{~d}$ & $0.39 \mathrm{~d}$ & $5.66 \mathrm{ba}$ \\
$\mathrm{M}-\mathrm{R} / \mathrm{NPK}$ & $8.06 \mathrm{~b}$ & $0.97 \mathrm{~b}$ & $0.47 \mathrm{~b}$ & $5.68 \mathrm{ba}$ \\
$\mathrm{M}-\mathrm{R} / \mathrm{R}+\mathrm{NK}$ & $8.54 \mathrm{a}$ & $1.00 \mathrm{a}$ & $0.51 \mathrm{a}$ & $5.67 \mathrm{ba}$ \\
$\mathrm{Sp}-\mathrm{R} / \mathrm{S}+\mathrm{NP}$ & $8.43 \mathrm{a}$ & $1.00 \mathrm{a}$ & $0.47 \mathrm{~b}$ & $5.78 \mathrm{a}$ \\
$\mathrm{MSE}$ & 0.3265 & 0.05396 & 0.0439 & 0.1900 \\
$\mathrm{CV} \%$ & 4.040 & 5.661 & 9.7601 & 3.539 \\
\hline
\end{tabular}

Means in column with the same letters are not significantly $(P \leq 0.05)$ different according to DNMRT.

Treatments without organic matter inputs did not significantly improve soil organic carbon, nitrogen or phosphorus. This suggests that the crop rotation management practices could not totally support annual increase of soil carbon because in the years with rotation practice that does not introduce organic matter and soil carbon was depleted. The practice of maizerape/marsh residue+NK and sweet potato-rape/straw+NP treatments could be rotated with either fallow/nil fertilizer or maize-rape/nil to permit more years of carbon sequestration than years of carbon depletion. It would therefore be inferred that combined incorporation of organic matter (in the forms of marsh residue or straw) with inorganic fertilizers enhanced total soil carbon, nitrogen and phosphorus increases at the uplands to maintain sustainable soil quality. The practice could also have reduced atmospheric $\mathrm{CO}_{2}$ and encouraged carbon sequestration for optimal crop production and to mitigate climate change effects. The nil organic matter input and sole inorganic fertilizer treatments could degrade the soils under long term use and encourage global warming with increasing atmospheric $\mathrm{CO}_{2}$.

\subsection{Biomass Carbon, Nitrogen and Phosphorus in Uplands}

Table 2 shows that Sp-R/S+NP treatment resulted in significantly $(P<0.05)$ higher biomass carbon, nitrogen and phosphorus (164.6049 mg kg-1,31.1449 mg kg-1, and $7.49 \mathrm{mg} \mathrm{kg}^{-1}$ resp.) in soils. This was followed by M-R/NK+R (153.3749 $\mathrm{mg} \mathrm{kg}^{-1}, 24.9349 \mathrm{mg} \mathrm{kg}^{-1}$ and $6.55 \mathrm{mg} \mathrm{kg}^{-1}$ resp.) that was significantly better than the other treatments.

Table 2. Upland biomass C, N, P with different treatments during 2000-2006

\begin{tabular}{|c|c|c|c|}
\hline \multirow[t]{2}{*}{ Treatments } & Biomass Carbon & Biomass Nitrogen & Biomass Phosphorus \\
\hline & \multicolumn{3}{|l|}{$\mathrm{mg} / \mathrm{kg}^{-1}$} \\
\hline $\mathrm{F} / \mathrm{nf}$ & $133.96 c$ & $22.13 c$ & $4.73 c$ \\
\hline $\mathrm{M}-\mathrm{R} / \mathrm{nf}$ & $139.71 c$ & $23.92 \mathrm{cb}$ & $5.46 c$ \\
\hline M-R/NPK & $128.97 \mathrm{c}$ & $22.09 c$ & $6.55 b$ \\
\hline $\mathrm{M}-\mathrm{R} / \mathrm{NK}+\mathrm{R}$ & 153.37b & $24.93 b$ & $7.49 \mathrm{a}$ \\
\hline $\mathrm{P}-\mathrm{R} / \mathrm{S}+\mathrm{NP}$ & $164.60 \mathrm{a}$ & $31.14 a$ & - \\
\hline MSE & 18.6885 & 4.4132 & 1.34995 \\
\hline CV\% & 12.8933 & 17.766 & 22.9267 \\
\hline
\end{tabular}


This suggests that microbial biomass carbon, nitrogen and phosphorus were readily available under the combined organic and inorganic fertilizer soil amendments (Chengli et al., 2009; Wu et al., 2007; Hao et al., 2008; Hanhua et al., 2010). This supports significantly higher maize grain, straw and cob wastes yields than treatment either with inorganic fertilizer or without fertilizer at all. Maize-rape/NPK treatment $\left(128.97 \mathrm{mg} \mathrm{kg}^{-1} \mathrm{C}, 22.09 \mathrm{mg} \mathrm{kg}^{-1} \mathrm{~N}\right.$ and $5.46 \mathrm{mg} \mathrm{kg}^{-1} \mathrm{P}$ resp.) performed abysmally low in contributing microbial carbon, nitrogen and phosphorus compared to treatments without fertilizer ( $F / n f$ and $M-R / n f)$. This suggests that in terms of building soil biomass carbon and nitrogen, use of sole inorganic NPK should be discouraged.

\subsection{Yield in Uplands}

Data on yield of maize (Table 3) shows that grain, straw and cob waste yields were consistent and significantly $(P<0.05)$ higher under $M-R / N K+R\left(8.24\right.$ tha $^{-1}, 7.85$ tha $^{-1}, 1.72$ tha $^{-1}$ resp.) than M-R/NPK (7.82tha ${ }^{-1}, 7.61$ tha $^{-1}, 1.67$ tha $^{-1}$ resp.) and the least yield was under M$\mathrm{R} / \mathrm{nf}$ treatment (1.83tha ${ }^{1}{ }^{1} 2.39$ tha $^{-1}, 0.43$ tha $^{-1}$ resp.). This suggests that soil conditions under $\mathrm{M}-\mathrm{R} / \mathrm{NK}+\mathrm{R}$ facilitated higher maize grain yield by $77.79 \%$ over $\mathrm{M}-\mathrm{R} / \mathrm{nf}$ treatment (Control). Improved soil conditions under $\mathrm{M}-\mathrm{R} / \mathrm{NK}+\mathrm{R}$ include increased soil carbon, nitrogen and phosphorus which were higher than in M-R/nf and M-R/NPK (Table 1). Also, over $68 \%$ straw materials were produced under $\mathrm{M}-\mathrm{R} / \mathrm{NK}+\mathrm{R}$ and $\mathrm{M}-\mathrm{R} / \mathrm{NPK}$ treatments that increased soil carbon stock (carbon sink) and improved soil quality for sustainable crop production. Treatments having increasing organic matter inputs in this study sustainably improved soil quality for optimal crop yield in the Subtropical China region Ultisol, could have reduced atmospheric $\mathrm{CO}_{2}$ and improved carbon sequestration in the soils.

Table 3. Upland maize yield during 2000-2009 with different treatments

\begin{tabular}{llll}
\hline Treatments & \multicolumn{1}{l}{ Maize grain } & Straw & Cob waste \\
\cline { 2 - 4 } & $\left(\mathrm{t} \mathrm{ha}^{-1}\right)$ & & \\
\hline M-R/nf & $1.83 \mathrm{bc}$ & $2.39 \mathrm{~b}$ & $0.43 \mathrm{~b}$ \\
M-R/NPK & $7.82 \mathrm{~b}(76.60 \%)$ & $7.61 \mathrm{a}(68.59 \%)$ & $1.67 \mathrm{a}$ \\
$\mathrm{M}-\mathrm{R} / \mathrm{NK}+\mathrm{R}$ & $8.24 \mathrm{a}(77.79 \%)$ & $7.85 \mathrm{a}(68.55 \%)$ & $1.72 \mathrm{a}$ \\
MSE & 4.9250 & 7.1711 & 1.8547 \\
CV\% & 0.8256 & 1.2047 & 1.457 \\
\hline
\end{tabular}

Means in column with the same letters are not significantly $(P \leq 0.05)$ different according to DNMRT $(\%)=$ Percent Yield difference from Maize-Rape/nil fertilizer

\subsection{Slope Lands Assessment}

Table 4 shows that at the slope lands during 2000 to 2006, treatment Sp-R/NP+S $(7.18 \mathrm{gkg}$ $\left.{ }^{1}\right)$ significantly $(P<0.05)$ enhanced total carbon accretion in soils. This was followed by $\mathrm{Pn}-$ $\mathrm{Bb} / \mathrm{NP}+\mathrm{S}\left(6.81 \mathrm{~g} \mathrm{~kg}^{-1}\right), \mathrm{M}-\mathrm{B} / \mathrm{NK}+\mathrm{R}\left(6.60 \mathrm{~g} \mathrm{~kg}^{-1}\right)$ and Sp-R/NPK $\left(6.52 \mathrm{~g} \mathrm{~kg}^{-1}\right)$ to be better than Sp-R/nf $\left(5.78 \mathrm{~g} \mathrm{~kg}^{-1}\right)$ and $\mathrm{F} / \mathrm{nf}\left(5.36 \mathrm{~g} \mathrm{~kg}^{-1}\right)$ treatments. The data reveals that treatments with combined organic and inorganic fertilizers sequestered significantly $(P<0.05)$ higher total carbon in soils than those with sole inorganic or without fertilizer application. The least total carbon (Table 4) was sequestered from F/nf $\left(5.36 \mathrm{~g} \mathrm{~kg}^{-1}\right)$ and Sp-R/nf $\left(5.78 \mathrm{~g} \mathrm{~kg}^{-1}\right)$. This suggests that under continuous cultivation, land areas cultivated without combined organic 
and inorganic fertilizer inputs could be susceptible to rapid degradation and contribute to global warming.

Total nitrogen was significantly $(P<0.05)$ higher under Sp-R/NP+S $\left(0.88 \mathrm{~g} \mathrm{~kg}^{-1}\right)$, followed by $\mathrm{Pn}-\mathrm{B} / \mathrm{NP}+\mathrm{S}\left(0.86 \mathrm{~g} \mathrm{~kg}^{-1}\right)$ and $\mathrm{M}-\mathrm{B} / \mathrm{NK}+\mathrm{R}\left(0.84 \mathrm{~g} \mathrm{~kg}^{-1}\right)$. The least total $\mathrm{N}$ was from Sp-R/NPK $\left(0.81 \mathrm{~g} \mathrm{~kg}^{-1}\right)$, Sp-Re/nf $\left(0.72 \mathrm{~g} \mathrm{~kg}^{-1}\right)$ and $\mathrm{F} / \mathrm{nf}\left(0.67 \mathrm{~g} \mathrm{~kg}^{-1}\right)$. Table 4 shows that treatments with combined organic and inorganic fertility amendments were superior in contributing total nitrogen to soils than the others.

Total phosphorus was not statistically different between treatments with combined organic and inorganic inputs and Sp-R/NPK (Table 4). They were however significantly $(P<0.05)$ higher than treatments without organic inputs.

Soil acid reaction values ranged from $\mathrm{pH} 4.97$ to 5.13 among the treatments, identifying a strong acid range (Table 4), that are within the range for optimal nutrients' uptake by crop roots. However, Sp-R/NPK treatment caused a significant decrease (Figure 4) in soil pH (pH 4.97); perhaps indicating that sole inorganic fertilizer (NPK) could acidify soils under long term use.

Table 4. Slope land total $\mathrm{C}, \mathrm{N}, \mathrm{P}$, and $\mathrm{pH}$ with treatments

\begin{tabular}{|c|c|c|c|c|}
\hline Treatments & $\begin{array}{l}\text { Total } \\
\text { carbon }\end{array}$ & $\begin{array}{l}\text { Total } \\
\text { nitrogen }\end{array}$ & $\begin{array}{l}\text { Total } \\
\text { phosphorus }\end{array}$ & $\mathrm{pH}$ \\
\hline & $\mathrm{g} / \mathrm{kg}$ & & $\mathrm{mg} / \mathrm{kg}$ & \\
\hline F/nf & $5.36 e$ & $0.67 e$ & $0.31 b$ & $5.03 \mathrm{ba}$ \\
\hline Sp-R/nf. & $5.78 d$ & $0.72 d$ & $0.31 b$ & $5.07 \mathrm{ba}$ \\
\hline Sp-R/NPK & $6.52 \mathrm{c}$ & $0.81 \mathrm{c}$ & $0.38 a$ & $4.97 b$ \\
\hline Sp-R/NP+S & $7.18 a$ & $0.88 a$ & $0.38 a$ & $5.13 a$ \\
\hline $\mathrm{Pn}-\mathrm{Bb} / \mathrm{NP}+\mathrm{S}$ & $6.81 \mathrm{~b}$ & $0.86 \mathrm{ba}$ & $0.38 a$ & $5.07 \mathrm{ba}$ \\
\hline $\mathrm{M}-\mathrm{B} / \mathrm{NK}+\mathrm{R}$ & $6.60 c$ & $0.84 b c$ & $0.40 a$ & $5.00 \mathrm{~b}$ \\
\hline MSE & 0.4474 & 0.07017 & 0.04827 & 0.14027 \\
\hline CV\% & 6.9746 & 8.6805 & 13.2087 & 2.78458 \\
\hline
\end{tabular}

\subsection{Microbial Biomass Carbon, Nitrogen and Phosphorus}

Table 5 presents data on microbial biomass carbon, nitrogen and phosphorus content of soils at the slope lands. The data shows that Sp-R/NPK+S $\left(132.66 \mathrm{mg} \mathrm{kg}^{-1}\right)$ followed by En$\mathrm{Bb} / \mathrm{NP}+\mathrm{S}\left(129.81 \mathrm{mg} \mathrm{kg}^{-1}\right)$ treatment significantly $(\mathrm{P}<0.05)$ credited soil with biomass carbon to be superior over Sp-R/NPK (125.13 $\left.\mathrm{mg} \mathrm{kg}^{-1}\right), \mathrm{Sp}-\mathrm{R} / \mathrm{nf}\left(107.27 \mathrm{mg} \mathrm{kg}^{-1}\right)$ and F/nf $(86.98$ $\left.\mathrm{mg} \mathrm{kg}^{-1}\right)$. Treatments lacking in organic inputs resulted in significantly low biomass carbon in the soils.

The Sp-R/NPK+S treatment contributed significantly $(\mathrm{P}<0.05)$ higher biomass nitrogen $\left(23.96 \mathrm{mg} \mathrm{kg}^{-1}\right.$ ) and was followed by En-Bb/NP+S $\left(21.76 \mathrm{mg} \mathrm{kg}^{-1}\right)$. These treatments significantly exceeded Sp-R/NPK (18.34 $\mathrm{mg} \mathrm{kg}^{-1}$ ) in contributing biomass nitrogen in this Ultisol on Slope lands in the region. The least biomass nitrogen was contributed by treatments without organic inputs (Table 5), in particular those without any form of fertilizer application. 
Table 5. Potato-Rape Slope land Microbial C, N and P with treatments during 2000-2008

\begin{tabular}{llll}
\hline Treatments & \multicolumn{1}{c}{ Biom. C } & Biom. $\mathbf{~}$ & Biom. $\mathbf{P}$ \\
\cline { 2 - 4 } & $\mathbf{m g k g}^{-1}$ & & \\
\hline F/nf & $86.982 \mathrm{~d}$ & $14.924 \mathrm{~d}$ & $4.984 \mathrm{~b}$ \\
$\mathrm{Sp}-\mathrm{R} / \mathrm{nf}$ & $107.265 \mathrm{c}$ & $16.359 \mathrm{dc}$ & $4.969 \mathrm{~b}$ \\
$\mathrm{Sp}-\mathrm{R} / \mathrm{NPK}$ & $125.131 \mathrm{~b}$ & $18.336 \mathrm{c}$ & $6.453 \mathrm{a}$ \\
$\mathrm{Sp}-\mathrm{R} / \mathrm{NPK}+\mathrm{S}$ & $132.66 \mathrm{a}$ & $23.956 \mathrm{a}$ & $7.351 \mathrm{a}$ \\
$\mathrm{En}-\mathrm{Bb} / \mathrm{NPK}+\mathrm{S}$ & $129.810 \mathrm{ba}$ & $21.756 \mathrm{~b}$ & $7.387 \mathrm{a}$ \\
$\mathrm{MSE}$ & 15.4542 & 4.59047 & 2.1252 \\
$\mathrm{CV} \%$ & 13.2971 & 24.0543 & 33.9687 \\
\hline \multicolumn{2}{c}{ Means in column with the same letters are not significantly $(P \leq 0.05)$ different according to DNMRT }
\end{tabular}

Microbial biomass phosphorus was significantly high under En-Bb/NPK+S $\left(7.39 \mathrm{mg} \mathrm{kg}^{-1}\right)$, $\mathrm{Sp}-\mathrm{R} / \mathrm{NPK}+\mathrm{S}\left(7.35 \mathrm{mg} \mathrm{kg}^{-1}\right)$ and Sp-R/NPK $\left(6.45 \mathrm{mg} \mathrm{kg}^{-1}\right)$ to be preferred over treatments without any form of fertilizer application. However treatments having organic matter inputs contributed higher biomass phosphorus than Sweet-rape/NPK that contains only inorganic fertilizer input. Tida et al. (2011) and Shoulong et al. (2010) observed in subtropical China region under a long-term experiment the trends of increase in microbial nutrients which suggests that when Slope land Ultisol are amended with combined organic and inorganic fertilizer materials, they generate sufficient labile carbon, nitrogen and phosphorus for sustainable crop production. This practice would improve quality of the Ultisol for sustainable crop production as well as improve soil carbon sink to reduce atmospheric $\mathrm{CO}_{2}$.

\subsection{Potato Yield in Slope Lands during 2000-2009}

Table 6 presents data on Potato yield from 2000-2009. It shows that Potato yield declined from 4.38 tha $^{-1}$ in 2000 to as low as 1.82 tha $^{-1}$ in 2008. The steady decline in Potato yield on the Slope land Ultisol may be partly explained by the lower levels of total carbon, $\mathrm{pH}$, nitrogen and phosphorus, biomass carbon, nitrogen and phosphorus in the Slope lands, compared with Upland fields. Perhaps this suggests that soil acidity may have increased over this study period. Further investigation would be necessary to ascertain cause of decline in potato yield on the subtropical China region Ultisol.

Table 6. Slope land potato fresh weight yield during 2000-2009

\begin{tabular}{ll}
\hline Year & Fresh Weight $\left(\mathbf{t ~ h a}^{-1}\right)$ \\
\hline 2000 & $4.38 \mathrm{a}$ \\
2001 & $3.43 \mathrm{cb}$ \\
2002 & $3.88 \mathrm{~b}$ \\
2003 & $3.76 \mathrm{~b}$ \\
2004 & $2.85 \mathrm{~d}$ \\
2005 & $3.04 \mathrm{~cd}$ \\
2006 & $3.27 \mathrm{~cd}$ \\
2007 & $1.53 \mathrm{f}$ \\
2008 & $1.82 \mathrm{fe}$ \\
2009 & $2.08 \mathrm{e}$ \\
MSE & 3.1789 \\
CV\% & 1.0585 \\
\hline Means in column with the same letters are not significantly $(P \leq 0.05)$ different according to DNMRT
\end{tabular}




\subsection{Criteria for Monitoring Soil Quality and Changing Trends}

To monitor soil quality, the treatment means for total carbon, total nitrogen and phosphorus, biomass carbon, nitrogen, phosphorus, $\mathrm{pH}$ and annual grain and fresh potato tuber yields were matched graphically as shown in figures 1 to 16 for both Uplands and slope land.

To fit determined threshold limits for each topographic location into the soil quality (SQ) equation, $S Q=f(S P, P, E, H, E R, B D, F Q, M I), S Q$ (Soil Quality) was taken as $S Q=f(S P, P)$. This is because $E, H, E R, B D, F Q$ and $M I$ were all assigned the best quality value of 1.0. Therefore soil properties and productivity (Grain yield) were evaluated on a scale of 1 to 5; where 1 is the best and 5 is the worst of quality conditions. Soils of the upland areas had higher total carbon, total nitrogen and total phosphorus (SP) and could be more stable against soil erosion (ER) better than the Slope land soils. They were assessed $S_{1}$ as against $S Q_{2}$ for Slope land soils; where $S_{1}$, represents higher quality soil over $S_{2}$. Slope lands recorded significant lower total carbon, nitrogen, $\mathrm{pH}$ and phosphorus and biomass carbon, nitrogen and phosphorus that could have resulted from effects of soil erosion. Also, productivity under Slope lands appears to be declining.

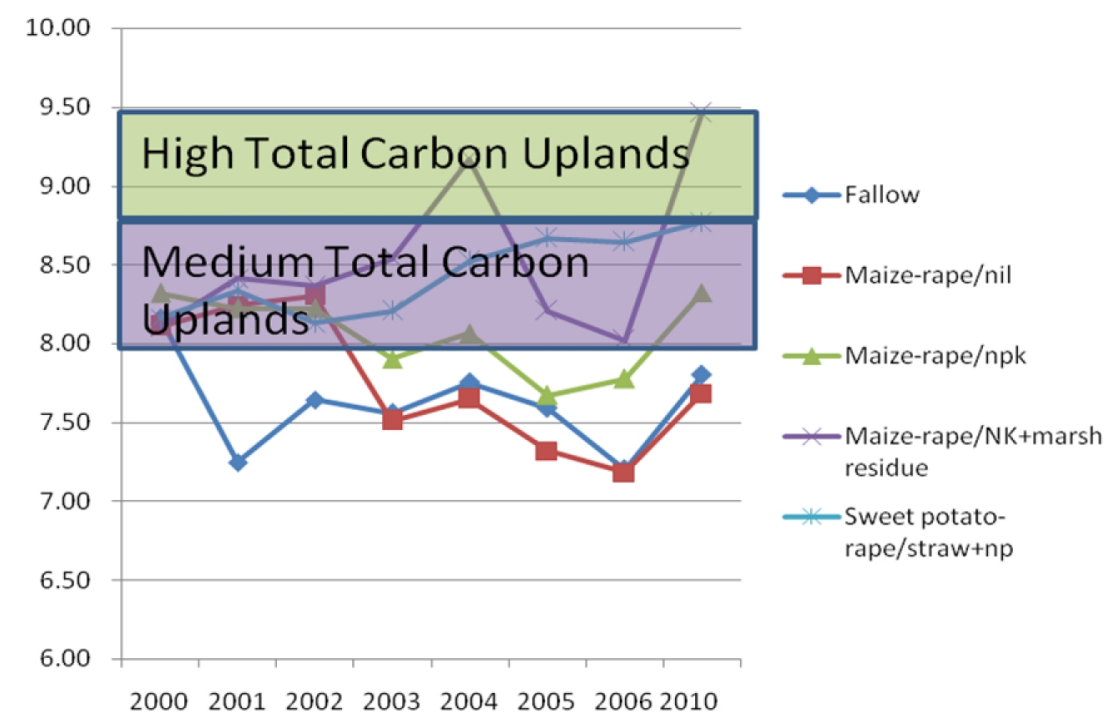

Fig 1. Total carbon in uplands (2000-2010) 


\section{Total Nitrogen (gkg-1)}

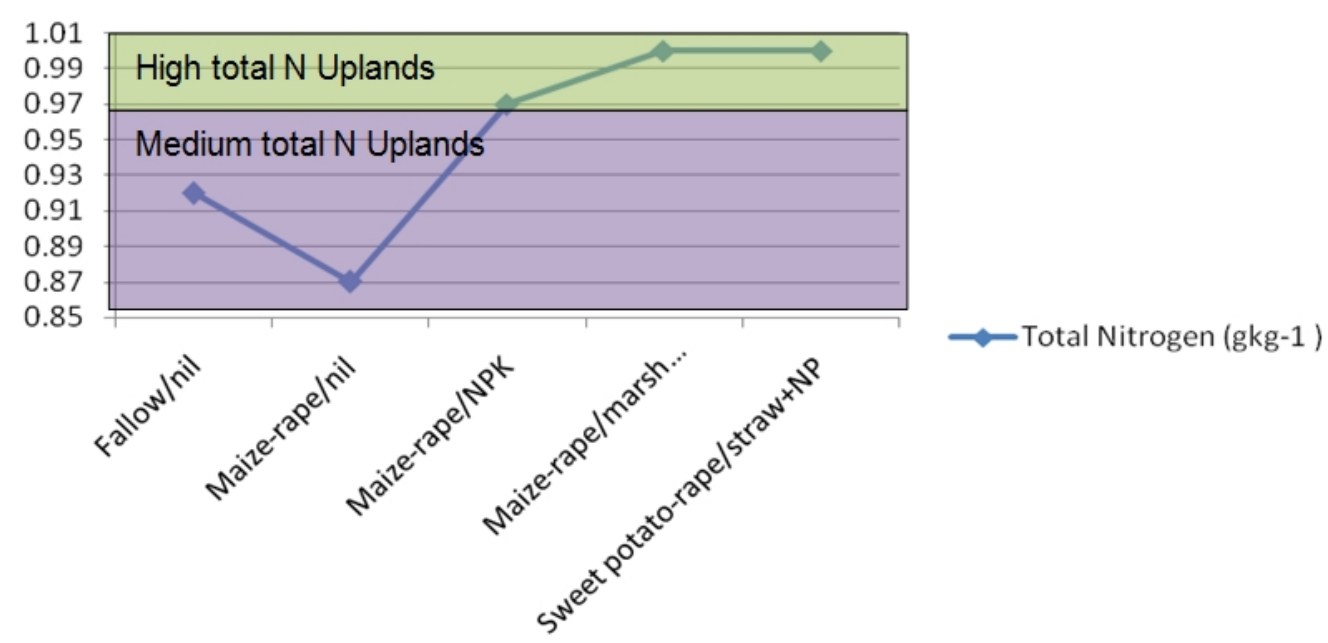

Fig 2. Total nitrogen in uplands (2000-2010)

Total Phosphorus (mgkg-1)

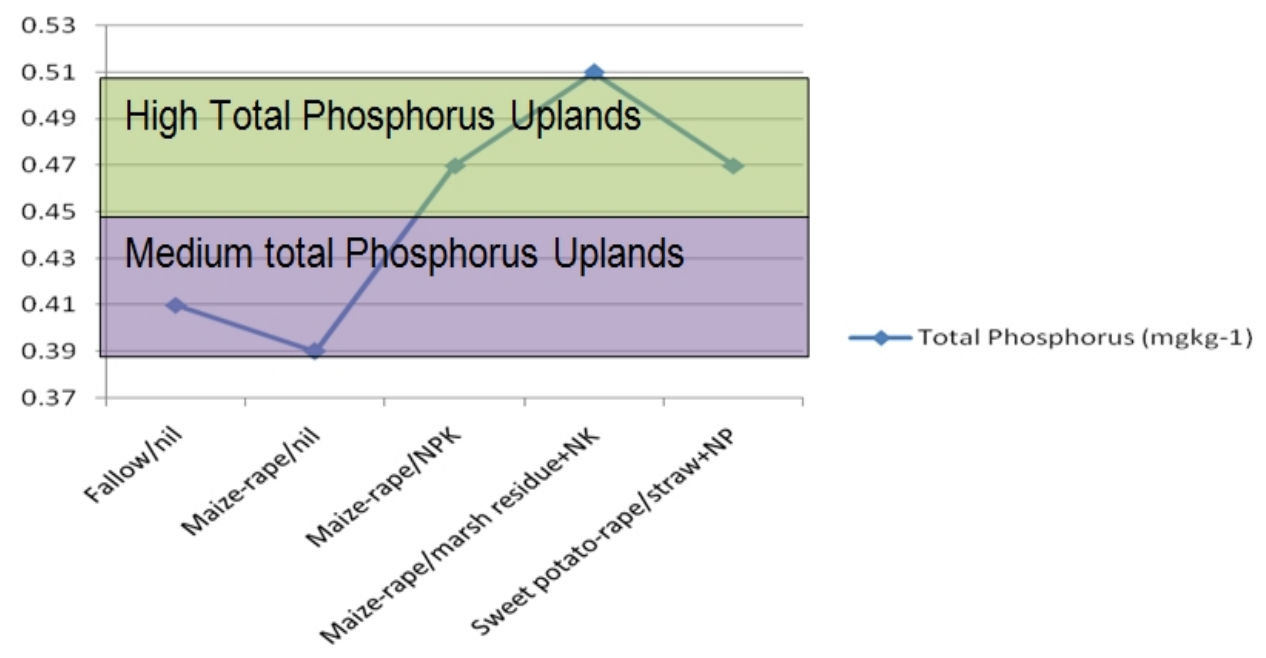

Fig. 3: Total phosphorus in uplands 


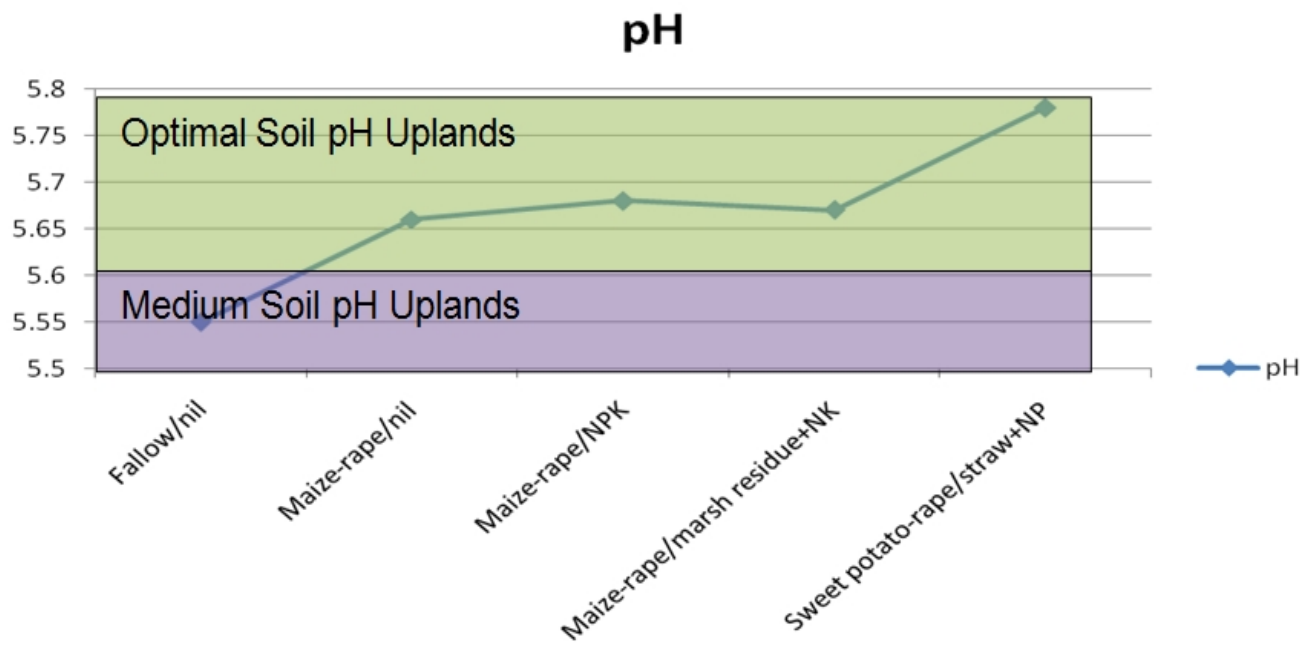

Fig. 4. Soil pH in uplands

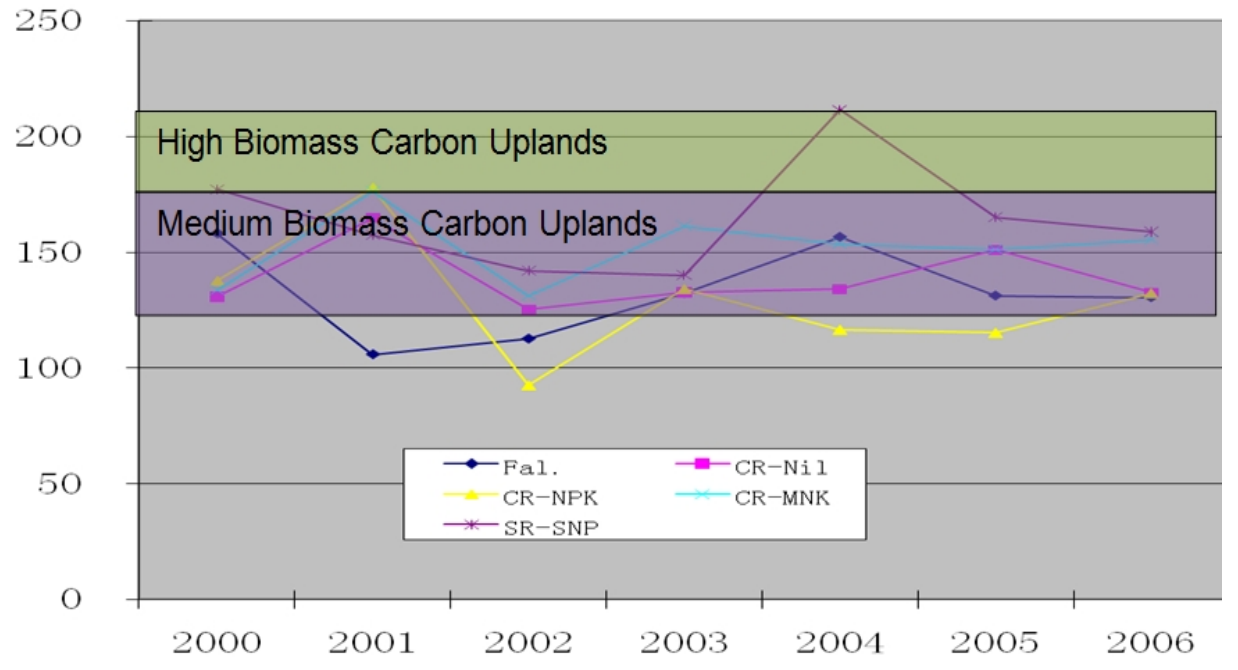

Fig. 5. Biomass carbon in uplands 


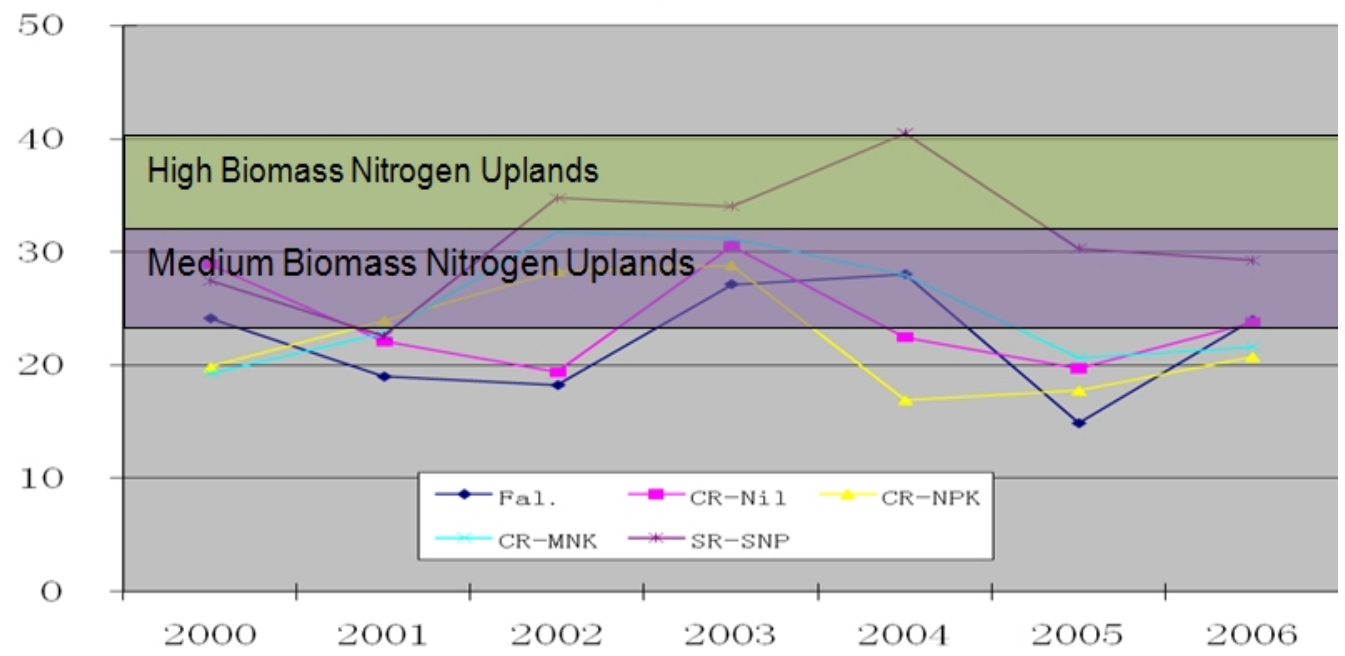

Fig. 6. Biomass nitrogen in uplands

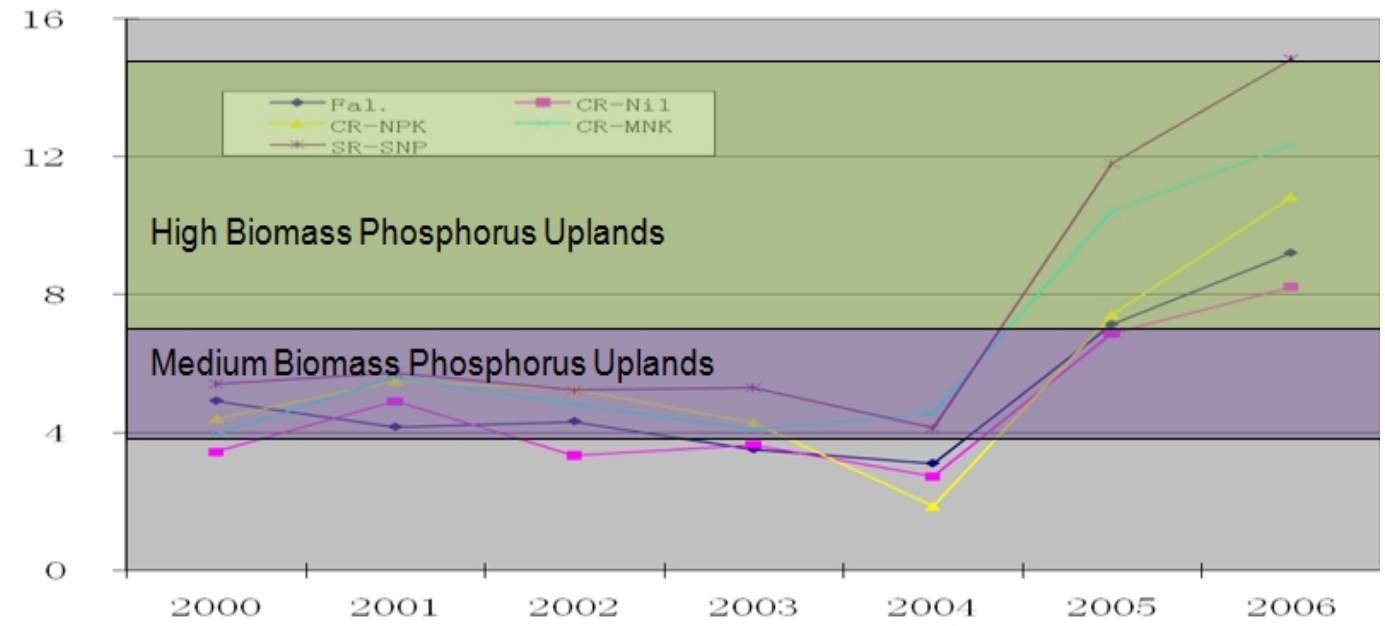

Fig 7. Biomass phosphorus in uplands 


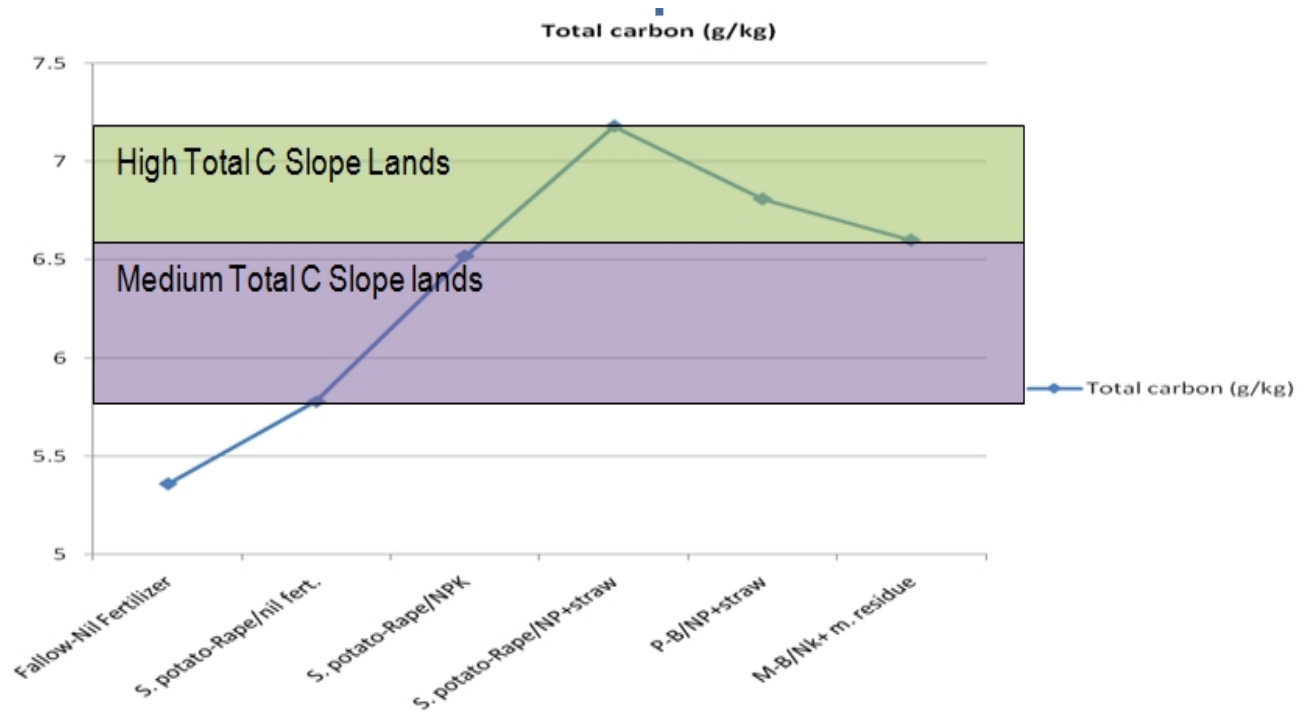

Fig 8. Total carbon in slope lands (2000-2008)

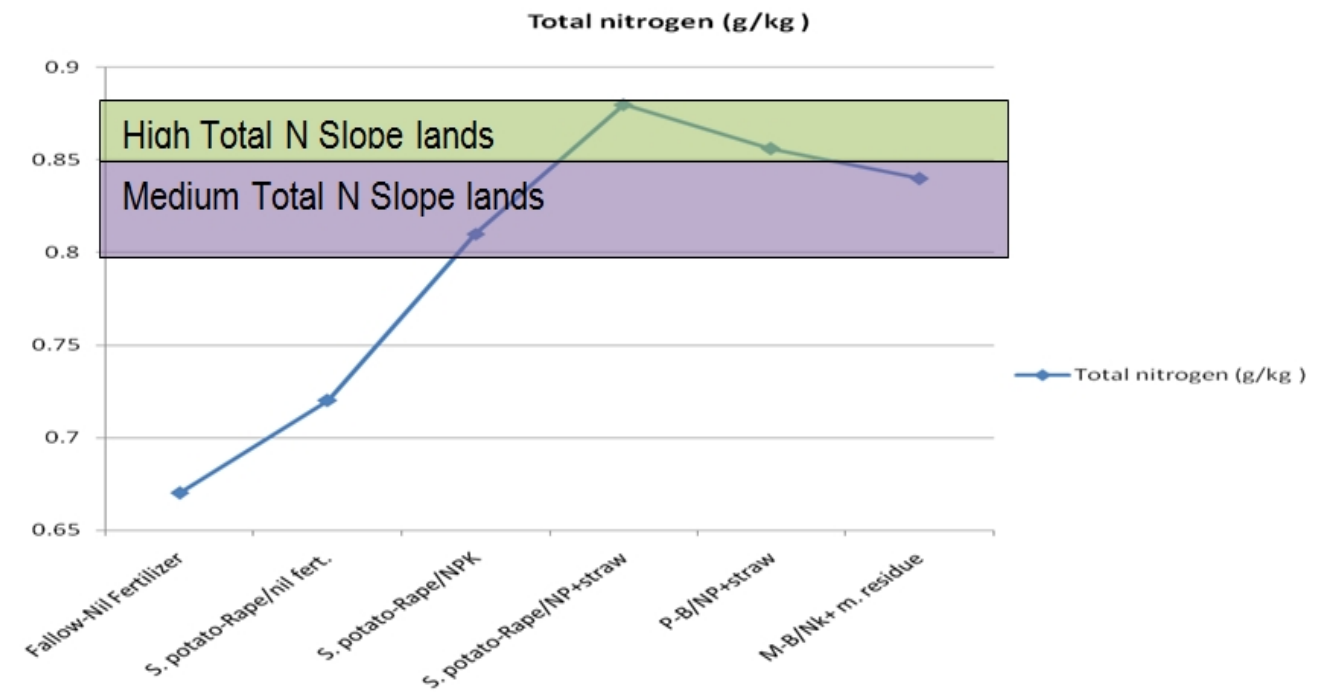

Fig . 9. Total nitrogen in slope lands (2000-2008) 


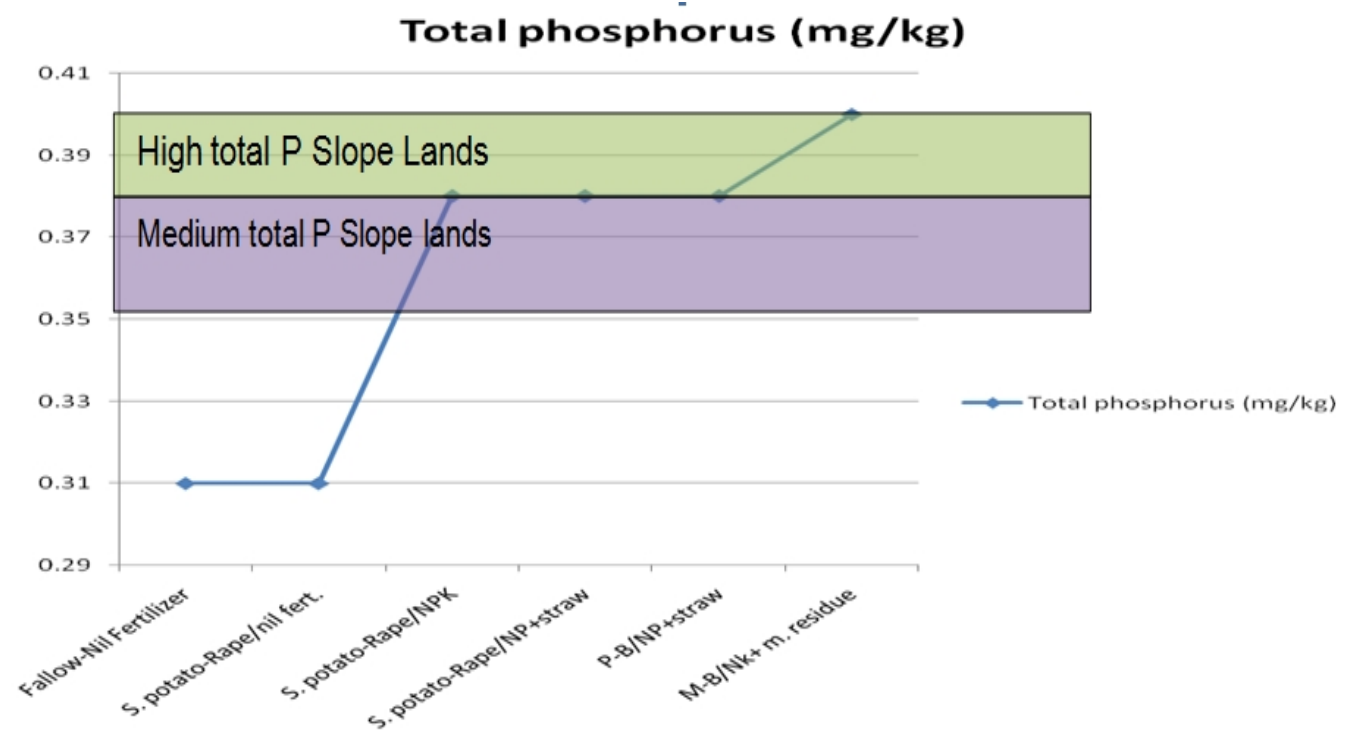

Fig 10. Total phosphorus in slope lands

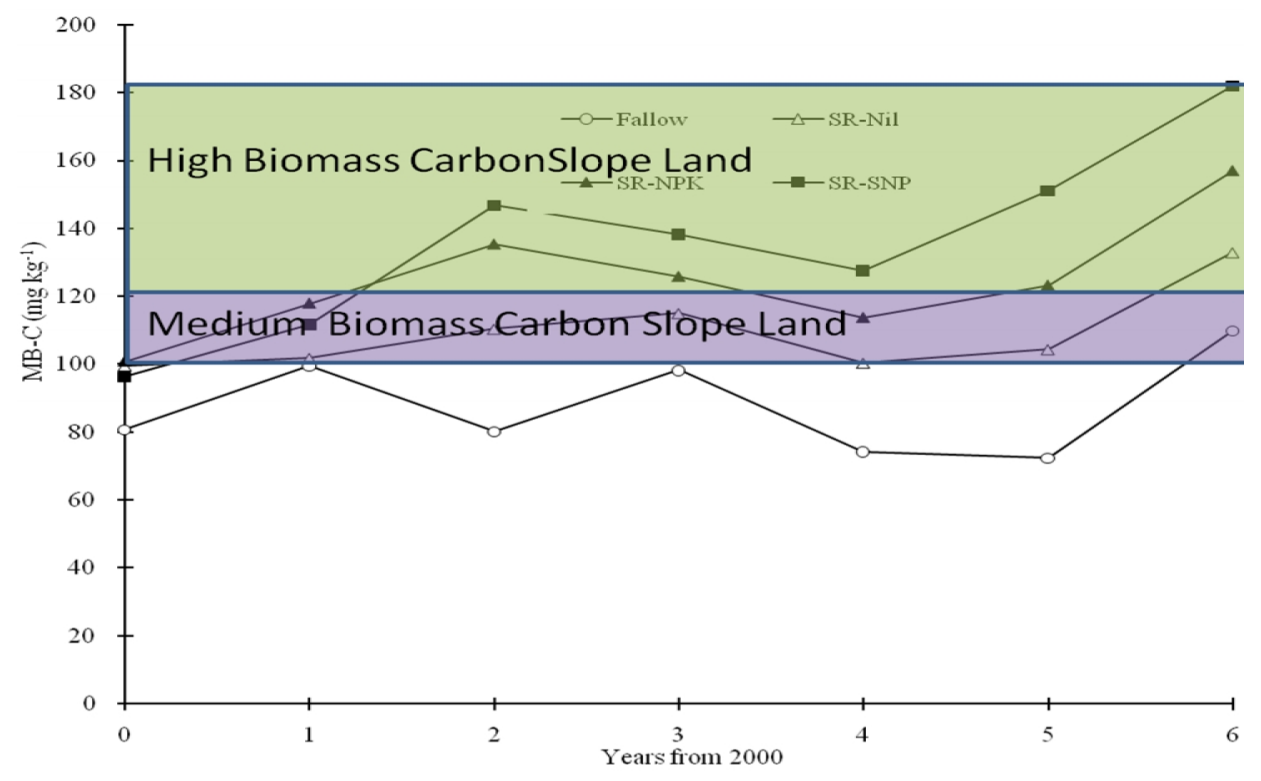

Fig. 11. Biomass carbon in slope lands (2000-2006) 


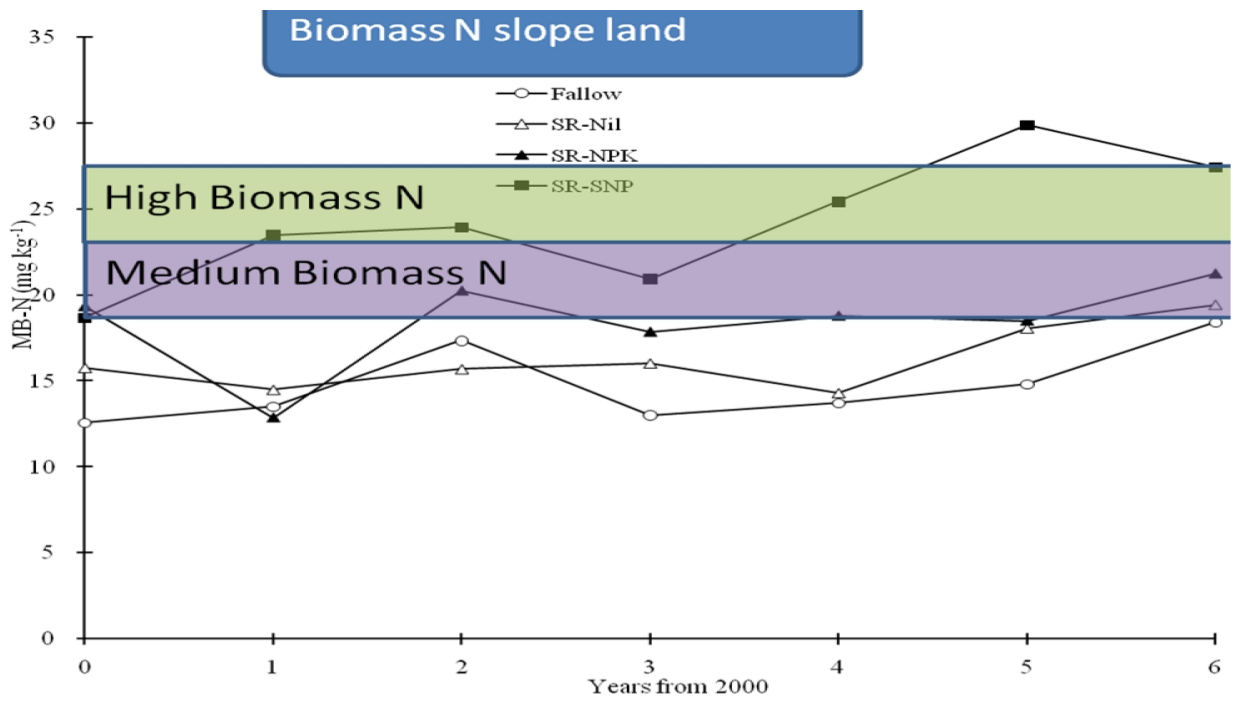

Fig. 12. Biomass nitrogen in slope lands

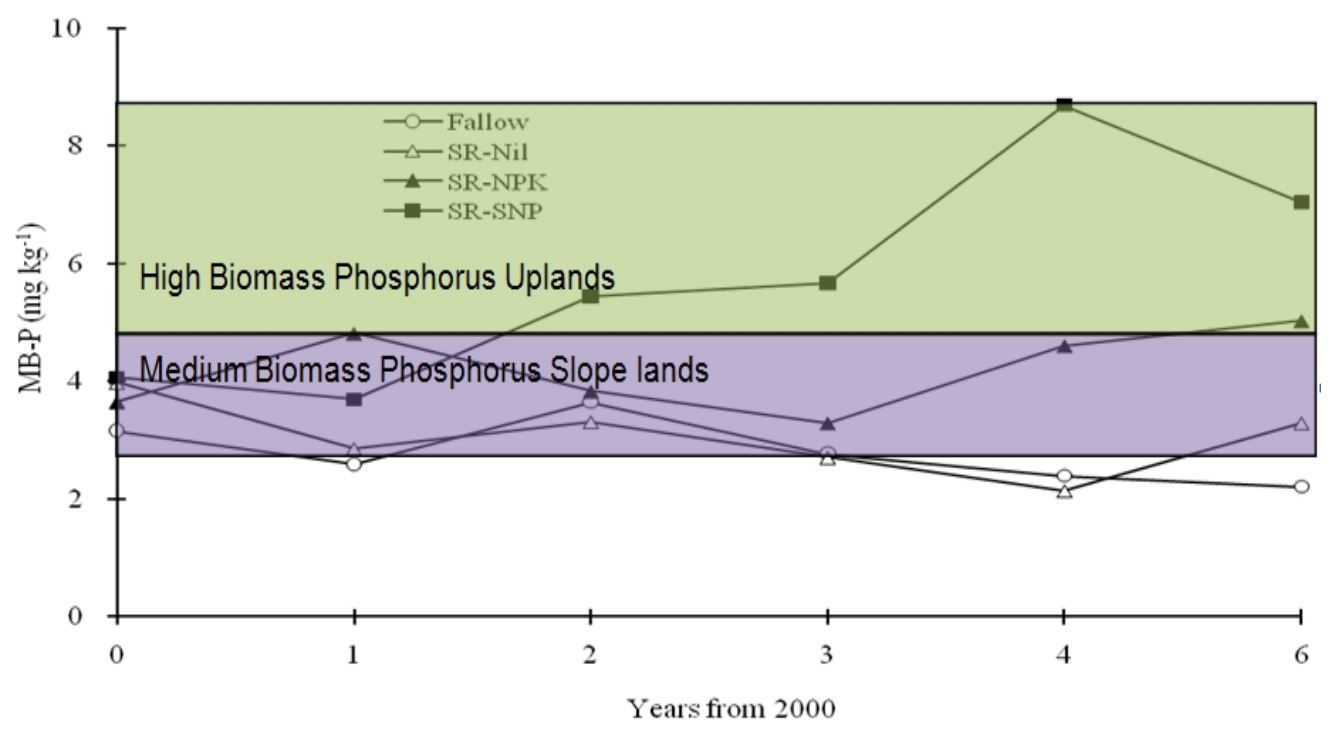

Fig. 13. Biomass phosphorus in slope lands (2000-2006) 


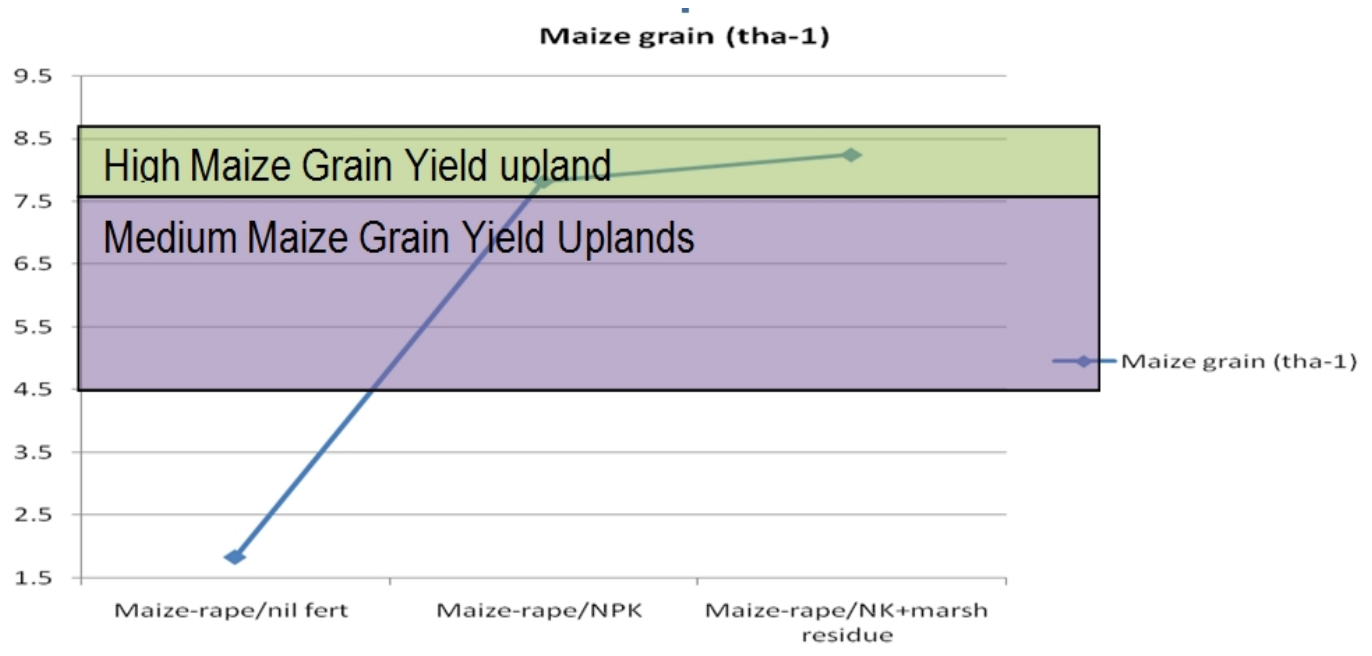

Fig. 14. Maize grain yield in uplands (point 3 on the curve is for Maize-rape/NK+marsh residue)

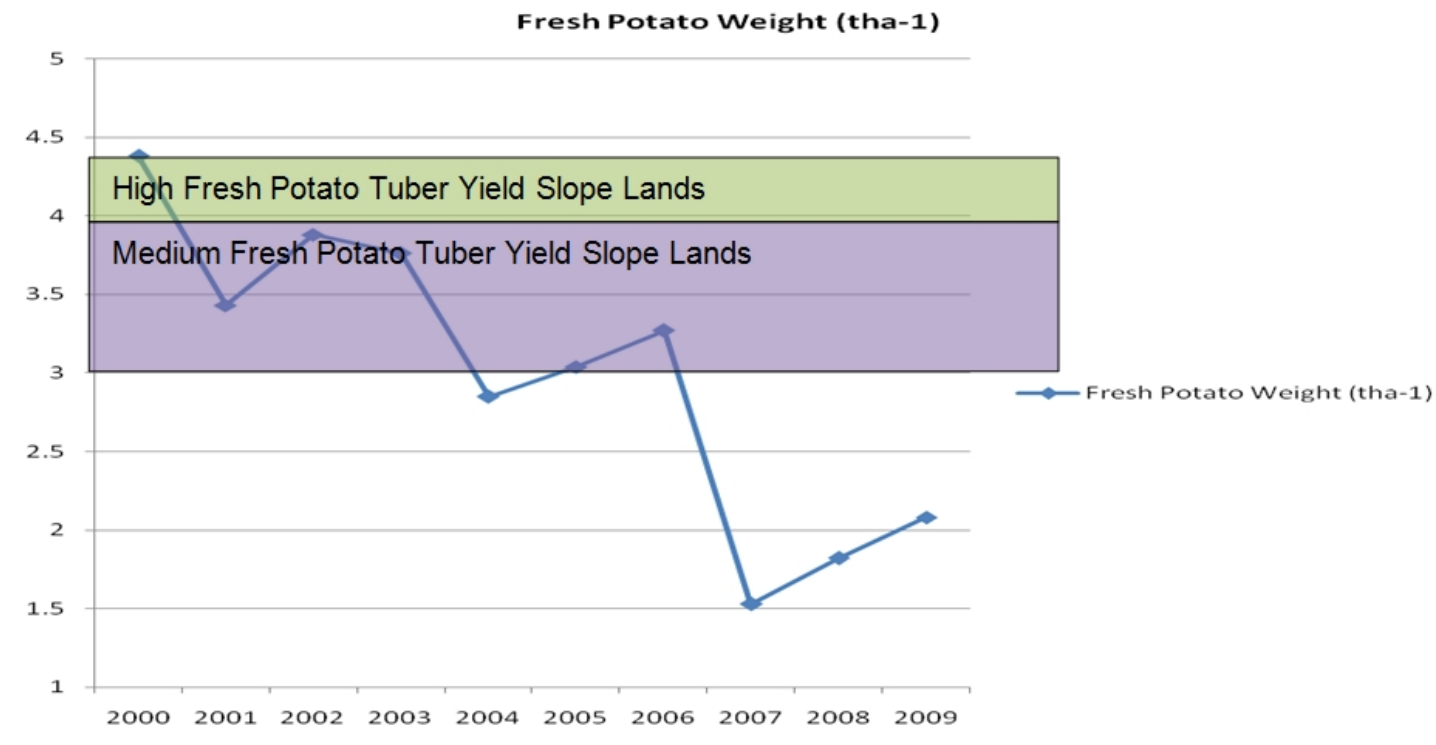

Fig. 15. Potato fresh tuber yields in slope lands 


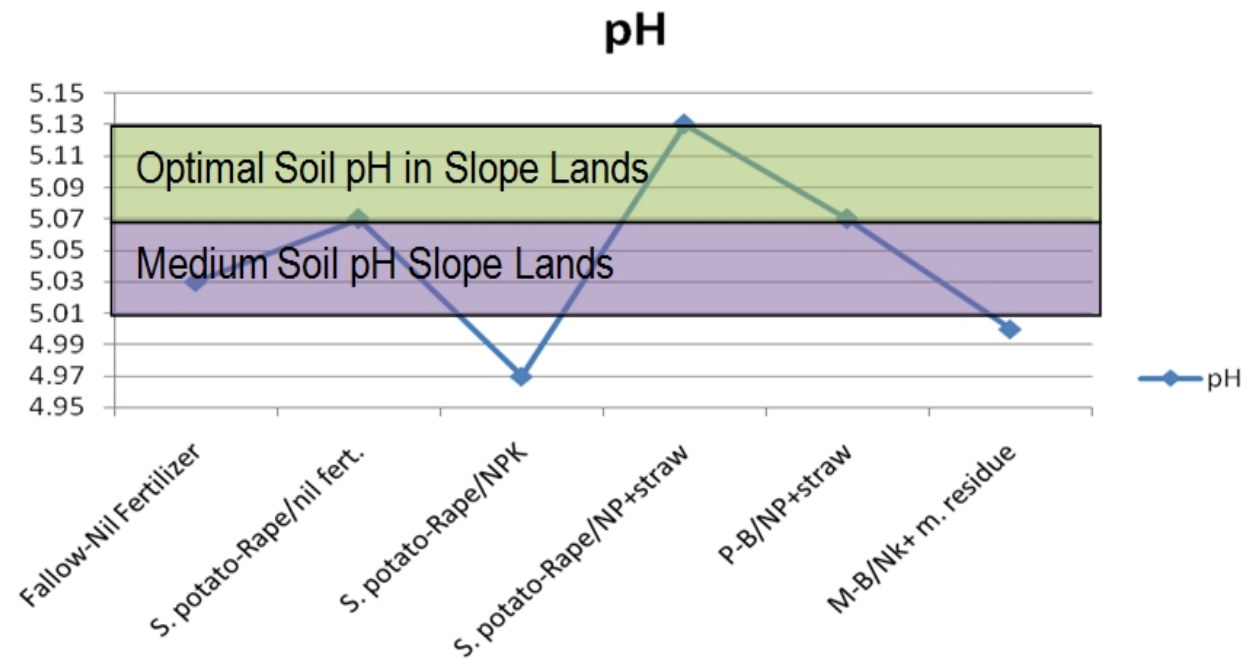

Fig. 16. Soil pH in slope lands Ultisol

Table 7. Summary of criteria for soil quality monitoring and evaluation in subtropical China region Ultisol

\begin{tabular}{|c|c|c|c|c|c|c|}
\hline \multirow[t]{2}{*}{ Nutrients/Grain Yield } & \multicolumn{3}{|c|}{ Soils in the Upland } & \multicolumn{3}{|c|}{ Soils in Slope Land } \\
\hline & High & Medium & Low & High & Medium & Low \\
\hline Total carbon $\left(\mathrm{gkg}^{-1}\right)$ & $\geq 8.8$ & $8.0-8.7$ & $<8.0$ & $\geq 6.8$ & $5.8-6.8$ & $<5.80$ \\
\hline Total Nitrogen $\left(\mathrm{gkg}^{-1}\right)$ & $\geq 0.97$ & $0.97-0.87$ & $<.87$ & $\geq 0.85$ & $0.8-8.5$ & $<0.8$ \\
\hline Total Phosphorus $\left(\mathrm{mgkg}^{-1}\right)$ & $\geq 0.49$ & $0.45-0.49$ & $<0.45$ & $\geq 0.39$ & $0.37-0.39$ & $<0.37$ \\
\hline Biomass carbon $\left(\mathrm{mgkg}^{-1}\right)$ & $\geq 175$ & $130-174$ & $<130$ & $\geq 125$ & $100-125$ & $<100$ \\
\hline Biomass nitrogen $\left(\mathrm{mgkg}^{-1}\right)$ & $\geq 33.0$ & $28-33.0$ & $<28$ & $\geq 24.0$ & $18-24$ & $<18.0$ \\
\hline $\begin{array}{l}\text { Biomass Phosphorus } \\
\left(\mathrm{mgkg}^{-1}\right)\end{array}$ & $\geq 7.5$ & $4.0-7.5$ & $<4.0$ & $\geq 5.8$ & $3.8-5.8$ & $<3.80$ \\
\hline Soil pH & $\geq 5.7$ & $5.55-5.7$ & $<5.55$ & $\geq 5.07$ & $5.01-5.07$ & $<5.01$ \\
\hline Maize grain yield (tha ${ }^{-1}$ ) & $\geq 7.50$ & $4.50-7.50$ & $<4.50$ & & & \\
\hline Potato Fresh weight $\left(\right.$ tha $\left.^{-1}\right)$ & & & & $\geq 4.0$ & $3.0-4.0$ & $<3.0$ \\
\hline
\end{tabular}

\section{CONCLUSION}

It would be inferred from this study that for sustainable management of upland and slope land Ultisol of subtropical China region, total carbon, total nitrogen, Soil $\mathrm{pH}$, total phosphorus, microbial biomass carbon, microbial biomass nitrogen, microbial biomass phosphorus fresh potato tuber and maize grain yield values obtained from a long term 
experiment in the zone and describing quality conditions for Ultisol in the region could be used to produce threshold limits for judging soil quality and changing trend over time. Also, combined application of organic matter (Maize-rape/marsh residue+NK and Sweet potatorape straw+NP), treatments significantly sequestered higher total carbon (8.54 and $8.43 \mathrm{~g}$ $\mathrm{kg}^{-1}$ resp.), total nitrogen (1.00 and $1.00 \mathrm{~g} \mathrm{~kg}^{-1}$ resp.) and total phosphorus ( 0.47 and 0.51 $\mathrm{mg} \mathrm{kg}^{-1}$ resp.) than others The combined incorporation of organic matter in the form of marsh residue or straw with inorganic fertilizers enhanced soil carbon, nitrogen and phosphorus, increased the availability in soils at both the upland and slope positions to maintain sustainable soil quality for optimal crop production. The least total carbon was sequestered from fallow-nil fertilizer $\left(5.36 \mathrm{~g} \mathrm{~kg}^{-1}\right)$ and sweet potato-rape/nil fertilizer $(5.78 \mathrm{~g}$ $\mathrm{kg}^{-1}$ ), suggesting that under continuous cultivation, land areas cultivated without combined organic and inorganic fertilizer inputs are susceptible to rapid degradation and contribute adversely to global warming. Continued use of Maize-rape/nil fertilizer and maize-rape/NPK and/or Fallow/nil fertilizer and Sweet potato-rape/nil fertilizer could degrade the soil by depleting soil carbon, increase soil acidity and encourage global warming by discouraging carbon sink.

Microbial biomass carbon, nitrogen and phosphorus increased and were more readily available under combined organic and inorganic fertilizer soil amendments and supported high soil quality. It resulted in significantly higher maize grain, straw and cob wastes yields than treatment either with inorganic fertilizer or without fertilizer at all. Grain, straw and cob waste yields were significantly $(\mathrm{P}<0.05)$ higher under maize-rape/NK+marsh residue $(8.24 \mathrm{t}$ $\mathrm{ha}^{-1}, 7.85 \mathrm{tha}^{-1}, 1.72 \mathrm{t} \mathrm{ha}^{-1}$ resp.) than maize-rape/NPK $\left(7.82 \mathrm{t} \mathrm{ha}^{-1}, 7.61 \mathrm{tha}^{-1}, 1.67 \mathrm{t} \mathrm{ha}^{-1}\right.$ resp.). The least yield was with maize-rape/nil fertilizer treatment $\left(1.83 \mathrm{t} \mathrm{ha}^{-1}{ }^{1} 2.39 \mathrm{t} \mathrm{ha}^{-1}\right.$, $0.43 \mathrm{t} \mathrm{ha}^{-1}$ resp.). Soil quality and threshold limits for nutrients at uplands were higher than the slope lands. Slope lands could have slight erosion threats that may account for its lower nutrient levels and quality status. However, soil pH at the slope lands was in the strong acid range. Developed threshold limits could serve as a ready guide for soil health and quality monitoring in the subtropical China region Ultisol to ensure sustainable agricultural production in the zone.

\section{ACKNOWLEDGEMENTS}

The authors deeply appreciate authorities of the Institute of Subtropical Agriculture, The Key Laboratory of Agro-ecological Processes in Subtropical Regions, The Chinese Academy of Sciences, China for availing Senior Visiting Scientist position to A. C. Odunze and providing data set for this study, as well as TWAS-UNESCO for offering a Research Fellowship to A. C. Odunze to accomplish this work. Also, the authors appreciate immensely the authorities of Ahmadu Bello University Zaria, Nigeria for authorizing the mission to China by A. C. Odunze.

\section{COMPETING INTERESTS}

Authors have declared that no competing interests exist.

\section{REFERENCES}

Andrews, S.S., Carroll, C.R. (2001). Designing a soil quality assessment tool for sustainable agro-ecosystem management. Ecological Applications, 11, 1573-1585. 
Arshad, M.A., Martin, S. (2002). Identifying critical limits for soil quality indicators in agroecosystems. Agriculture, Ecosystems \& Environment, 88(2), 153-160.

Barrios, E., Trejo, M.T. (2003). Implications of local soil knowledge for integrated soil fertility management in Latin America. Geoderma, 111, 217-231.

Brookes, P.C., Powlson, D.S., Jenkinson, D.S. (1982). Measurement of Microbial Biomass phosphorus in Soils. Soil Biol Biochem, 14, 319-329.

Brookes, P.C., Landan, A., Pruden, G., Jenkinson, D.S. (1985). Chloroform Fumigation and the Release of Soil Nitrogen: a rapid direct extraction method for measuring microbial biomass nitrogen in soil. Soil Biology \& Biochemistry, 17, 837-842.

Chengli Tong, Heai Xiao, Guoyong Tang, Hongquig Wang, Tieping Huang, Haiao Yia, Syers J. Keith, Yong Li, Shoulong Liu, Jinshui Wu. (2009). Long-term fertilizer effects on organic carbon and total nitrogen and coupling relationships of $\mathrm{C}$ and $\mathrm{N}$ in paddy soils in subtropical China. Soil Tillage Research, 106(2009), 8-14.

Doran, J.W., Parkin, T.B. (1994). Defining and assessing soil quality. In: Doran, J.W., Coleman, D.C., Bezdicek, D.F., Stewart, B.A. (Eds.), Defining Soil Quality for a Sustainable Environment. Soil Science Society of America Special Publication, vol. 35. Soil Science Society of America, Madison, Wisconsin, pp. 3-21.

Doran, J.W., Sarrantonio, M., Liebig, M.A. (1997). Soil health and sustainability. Adv. Agron., $56,1-54$.

Doran, J.W., Sarrantonio, M., Liebig, M. (1996). Soil health and sustainability. In: Sparks, D.L. (Ed.), advances in Agronomy, Vol. 56. Academic Press, San Diego, pp. 1-54.

Doran, J.W., Safley, M. (1997). Defining and assessing soil health and sustainable productivity. In: Pankhurst, C. et al. (eds.). Biological indicators of soil health. Wallingford, UK: CAB International. p. 1-28.

Doran, J.W., Zeiss, M.R. (2000). Soil health and sustainability: managing the biotic component of soil quality. Applied Soil Ecology, 15, 3-11.

Doran, J.W. (2002). Soil health and global sustainability: translating science into practice. Agriculture, Ecosystem \& Environment, 88, 119-127.

Duiker, S.W. (2011). Effect of Land Use and Soil Management on Soil Properties and Processes. In Soil Hydrology, Land Use and Agriculture: Measuring and Modelling (Manoj K. Shukia Ed). New Mexico State University USA, pp. 291-311.

Gomez, A.A., Swete Kelly, D.E., Syer, K.K., and Coughlan, K.J. (1996). Measuring sustainability of agricultural systems at the farm level. Pp 401-409. In: Methods for Assessing Soil Quality, J.W. Doran and A.J. Jones (Eds); Special publication no. 49, Soil Science Society of America, Madison, USA.

Gregorich', E.G., Carter, M.R., Angers, D.A., Monreall, C.M., Ellerta, B.H. (1994). Towards a minimum data set to assess soil organic matter quality in agricultural soils. Canadian Journal of Soil Science, 367-385.

Hanhua Zhu, Jinshui Wu, Daoyou Huang, Qihong Zhu, Shoulong Liu, Yirong Su, Wenxue Wei, J. Keith Syers, Yong Li. (2010). Improving fertility and productivity of a highly weathered upland soil in subtropical China by incorporating rice straw. Plant Soil, 331, 427-437.

Hao, X.H., Liu, S.L., Wu, J.S., Hu, R.G., Tong, C.L., Su, Y.Y. (2008). Effect of Long-term application of inorganic amendments on soil organic matter and microbial biomass in three subtropical paddy soils. Nutr Cycl Agroecosyt, 81, 17-24.

Hedlund, A., Witter, E., An, B.X. (2003). Assessment of N, P and K management by nutrient balances and flows on peri-urban smallholder farms in southern Vietnam. Eur. J. Agron., 20, 71-87.

Institute of Soil Science, Chinese Academy of Sciences (ISSCAS). (1978). Soil Physical and Chemical Analysis.Shanghai Sciences and Technology Press, Shanghai, pp 62,132. 
Jenkinson, D.S., Powlson, D.S. (1976). The effect of biocidal treatments on metabolism in soils: A method for measuring biomass. Soil Biol Biochem, 8, 209-213.

Karlen, D.L., Mausbach, M.J., Doran, J.W., Cline, R.G., Harris, R.F., Schuman, G.E. (1997). Soil quality: a concept, definition, and framework for evaluation (a guest editorial). Soil Sci. Soc. Am. J., 61, 4-10.

Lal, R., Stewart, B.A. (1995). Soil Management: Experimental Basis for Sustainability and Environmental Quality. Advances in Soil Science CRC Press, Boca Raton, Florida.

Larson, W.E., Pierce, F.J. (1994). The dynamics of soil quality as a measure of sustainable management. Pages 37 - 51 in J. W. Doran, D. C. Coleman, D. F. Bezdicek and B. A. Stewart, eds. Defining soil quality for a sustainable environment. SSSA-Special Publication 35. Soil Science Society of America, Madison, WI, USA.

Parr, J.F., R.I. Papendick, S.B. Hornick and R.E. Meyer (1992). Soil quality: attributes and relationship to alternative and sustainable agriculture. Am. J. Alternative Agric., 7, 5-11.

Ramankutty, N., Evans, A.T., Monfreda, C., Foley, J.A. (2008). Farming the Planet: 1. Geographic distribution of global agricultural lands in the year 2000. Global Biogenchemical Cycles, 2(1), GB1003.

Reginald Ebhin Masto, Chhonka, Pramod K., Singh, Dhyan, Patra, Ashokk. (2007). Soil quality response to long- term nutrient and crop management on a semi-arid Inceptisol. Agriculture, Ecosystems \& Environment, 118(1-4), 130-142.

Steer, A. (1998) Making development sustainable. Adv. Geo-Ecol., 31(1998), 857-865.

Shoulong, Liu, Yong, Li, Jinshui, Wu, Daoyou, Huang, Yirong, Su, Wenxue, Wei. (2010). Spatial variability of soil microbial biomass carbon, nitrogen and phosphorus in a hilly red soil landscape in subtropical China. Soil Science and Plant Nutrition, 56, 693-704.

Tida, Ge, San'an, Nie, Jinshui, Wu, Jianlin, Shen, He'ai, Xiao, Chengli, Tong, Danfeng, Huang, Yun Hong, Kaolwasaki (2011). Chemical properties, microbial biomass and activity differ between soils of organic and conventional horticultural systems under greenhouse and open field management: a case study. Journal of Soil Sediments, 11, 25-36.

United States Department of Agriculture. (USDA). Natural Resources Conservation Services (1998). Keys to Soil Taxonomy. $8^{\text {th }}$ Edition. P 326.

Vance, E.D., Brookes, P.C., Jenkinson, D.S. (1987). An extraction method for measuring soil microbial biomass C. Soil Biol Biochem, 19, 703-707.

Wu, J. (2011). Carbon accumulation in paddy ecosystems in subtropical China: evidence from landscape studies. European Journal of Soil Science, 62, 29-34.

Wu, Jinshui, Min Huang, He-Ai Xiao, Yi-Rong Su, Cheng-Li Tong, Dao - You Huang, J. Keith Sters. (2007). Dynamics in microbial immobilization and transformations of phosphorus in highly weathered subtropical soil following organic amendments. Plant Soil, 290, 333-342.

Wu, J., Joergensen, R.G., Pommerening, B.B. (1990). Measurement of soil microbial biomass by fumigation-extraction-an automated procedure. Soil Boil. Biochem., 20, 1167-1169.

Wu, J., He, ZL, Wei, W.X., O'Donnell, A.G., Syers, J.K. (2000). Quantifying Microbial Biomass Phosphorus in Acid Soils. Bio Fertile. Soils, 35, 500- 507.

Zhang, W.L., Tian, Z.X., Zhang, N., Li, X.Q. (1996). Nitrate pollution of groundwater in northern China. Agricult, Ecosyst Environ, 59, 223-231.

(C) 2012 Odunze et al.; This is an Open Access article distributed under the terms of the Creative Commons Attribution License (http://creativecommons.org/licenses/by/3.0), which permits unrestricted use, distribution, and reproduction in any medium, provided the origin al work is properly cited. 